\title{
Is grand multiparity a risk factor for the development of postmenopausal osteoporosis?
}

This article was published in the following Dove Press journal:

Clinical Interventions in Aging

\author{
Nuri Peker' \\ Özge Çeliker Tosun² \\ 'Department of Obstetrics and \\ Gynecology, İstinye University \\ Bahçeșehir Liv Hospital, Istanbul, \\ Turkey; ${ }^{2}$ School of Physiotherapy, \\ Dokuz Eylul University, Izmir, Turkey
}

Correspondence: Nuri Peker Ușak University Training and Research Hospital, Fevzi Çakmak Mahallesi, Gazi Blv. Yanyolu No: 50, Ușak Merkez, Ușak 64300, Turkey

Tel +905072352921

Emaildr.ata1980@hotmail.com
Objective: In this study, we investigated the relationship between the development of postmenopausal osteoporosis and parity.

Materials and methods: The retrospective study included 129 postmenopausal women who were divided into three groups depending on the number of parity: Group I, <5; Group II, 5-9; and Group III, $\geq 10$. The mean age of the subjects was $57.71 \pm 5.02$ years.

Results: No significant difference was found among the three groups regarding body mass index values, duration of menopause, mean thyroid stimulating hormone values and frequency of diabetes. Among the three groups, no significant difference was found in terms of the frequency of lumbar osteoporosis ( $p>0.05)$, whereas a significant difference was found regarding the frequency of femoral osteoporosis ( $p=0.012 ; p<0.05$ ).

Conclusion: It was revealed that femoral bone mineral density significantly decreased as the number of parity increased.

Keywords: menopause, osteoporosis, parity

\section{Introduction}

Osteoporosis is a chronic metabolic bone disorder characterized by low bone mineral density (BMD) and increased fracture risk. With the ageing world population, osteoporosis remains a significant public health problem today and for the future. ${ }^{1}$ The exact prevalence of osteoporosis remains unknown, but it may vary among countries and even among ethnic groups in the same country. Osteoporosis is known to be affected by numerous factors, including ethnic origin, socioeconomic status, diet, physical activity, lifestyle, alcohol and drug abuse, and insufficient exposure to sunlight. ${ }^{1,2}$ Moreover, postmenopausal osteoporosis is associated with adolescent pregnancy, number and frequency of parity, and duration and frequency of lactation. ${ }^{2}$ The mainstay diagnosis of osteoporosis is based on the assessment of BMD at the femoral neck and the anterior-posterior lumbar spine using dual-energy X-ray absorptiometry (DXA). ${ }^{1,2}$ A T-score $\leq-2.5$ standard deviation (SD) is considered osteoporosis. ${ }^{1,2}$

In this retrospective study, we aimed to investigate the relationship between the development of postmenopausal osteoporosis and parity in patients with low socioeconomic status.

\section{Materials and methods}

The retrospective study reviewed the clinical records of the postmenopausal patients admitted to Altinozu State Hospital, Hatay, Turkey, between 1 April 2011 and 1 April 2012. Deidentified patient data were used in this study. Institutional approval was obtained from Altınözü State Hospital Review Board. Patient consent to review their medical 
records was not required by the review board, due to the retrospective nature of the study. The patients were admitted because of back pain, hip pain, or routine postmenopausal follow-up. The patients were divided into three groups depending on the number of parity: Group I, <5; Group II, 5-9; and Group III, $\geq 10$.

Patients in the premenopausal period, aged over 65 years, and those with a body mass index (BMI) $<20 \mathrm{~kg} / \mathrm{m}^{2}$ or $>35 \mathrm{~kg} / \mathrm{m}^{2}$ and a history of smoking or alcohol abuse, were excluded from the study. Patients with a systemic or metabolic disease, such as hyperthyroidism, hypothyroidism, diabetes mellitus type I, chronic asthma, chronic arthritis, chronic inflammatory bowel disease and Cushing's syndrome, were also excluded from the study. In addition, patients using heparin, bisphosphonates, thyroxin, hormone replacement therapy, calcium, vitamin D or thiazide diuretics were excluded from the study.

Age, gravida, parity, BMI, age at the onset of menopause, duration of menopause, complaints at hospital admission, and physical signs and symptoms were recorded. Thyroid function tests were evaluated for each patient. BMD was assessed using DXA (Norland Eclipse XR; Norland Corp., Ford Atkinson, WI, USA), and the assessments were evaluated for each patient. Osteoporosis was defined as a $\mathrm{T}$-score of $\leq-2.5$, and osteopenia was defined as a $\mathrm{T}$-score between -1.0 and -2.5 .

\section{Statistical analysis}

All data were analyzed using IBM SPSS Statistics 22.0 (IBM Corporation, Armonk, NY, USA). Normal distribution was tested using a Shapiro-Wilks test. Data were evaluated using descriptive statistics (mean, SD, frequency). Quantitative data with normal distribution were compared among the groups using one-way ANOVA, followed by a Tukey's HSD test. Non-normally distributed parameters were compared using a Kruskal-Wallis test, followed by a Mann-Whitney $U$ test. Qualitative data were compared using a chi-square test. A $p$-value of $<0.05$ was considered significant.

\section{Results}

The retrospective study included 129 postmenopausal women aged 48-65 years who were admitted to Altinozu State Hospital, Hatay, Turkey between 1 April 2011 and 1 April 2012. The mean age was $57.71 \pm 5.02$ years. The main complaint at admission was backache or hip pain; however, some patients were evaluated during routine postmenopausal follow-up. In Turkey BMD is assessed with DXA every 2 years in the postmenopausal period.
Table I Characteristics of the patients

\begin{tabular}{|c|c|c|c|c|}
\hline \multirow[t]{3}{*}{ Characteristics } & \multicolumn{3}{|l|}{ Parity } & \multirow[t]{3}{*}{$p$-value } \\
\hline & $<5(n=27)$ & $5-9(n=35)$ & $\geq 10(n=67)$ & \\
\hline & $\overline{\text { Mean } \pm \text { SD }}$ & Mean \pm SD & Mean \pm SD & \\
\hline Age (years) & $55.26 \pm 4.78$ & $56.69 \pm 5.14$ & $57.22 \pm 4.58$ & $0.062^{\#}$ \\
\hline BMI & $33.47 \pm 7.9$ & $32.35 \pm 6.4$ & $30.3 \pm 5.2$ & $0.055^{\#}$ \\
\hline Parity (median) & $\begin{array}{l}3.56 \pm 1.72 \\
(4)\end{array}$ & $\begin{array}{l}7.43 \pm 1.12 \\
(8)\end{array}$ & $\begin{array}{l}11.52 \pm 1.67 \\
\text { (II) }\end{array}$ & $0.00 I^{\#, *}$ \\
\hline $\begin{array}{l}\text { Duration of } \\
\text { menopause } \\
\text { (years) }\end{array}$ & $7.19 \pm 6.58$ & $7.03 \pm 4.56$ & $8.87 \pm 5.32$ & $0.185^{\#}$ \\
\hline TSH & $1.64 \pm 0.88$ & $\mathrm{I} .4 \mathrm{I} \pm 0.96$ & $1.34 \pm 0.72$ & $0.304^{\#}$ \\
\hline $\begin{array}{l}\text { Type II diabetes, } \\
\text { n (\%) }\end{array}$ & $8(29.6 \%)$ & $6(17.1 \%)$ & $26(38.8 \%)$ & $0.079 \ldots$ \\
\hline
\end{tabular}

The hospital is located in the Mediterranean region of southern Turkey, where Arabs constitute the most common ethnic group. All the patients studied were illiterate women with low socioeconomic status, most of whom were married and had their first delivery before the age of 18 years. Clinical records indicated that none of the women had a history of alcohol or drug abuse. The records also showed that their diet mostly consisted of meat and milk products because their primary source of income was agriculture and livestock breeding.

Table 1 presents the demographic characteristics of the women in the three groups. No significant difference was found among the three groups in terms of mean age ( $p=0.062$ ). Moreover, no significant difference was found among the three groups with regards BMI values, the duration of menopause, mean thyroid stimulating hormone values and frequency of type II diabetes.

Table 2 presents the frequency of osteopenia and osteoporosis at the femoral neck and the anterior-posterior

Table 2 Bone mineral density at the femoral neck and the anterior-posterior lumbar spine

\begin{tabular}{|c|c|c|c|c|}
\hline \multirow{3}{*}{$\begin{array}{l}\text { DXA } \\
\text { findings }\end{array}$} & \multicolumn{3}{|l|}{ Parity } & \multirow[t]{3}{*}{ p-value } \\
\hline & $<5$ & 5-9 & $\geq 10$ & \\
\hline & n (\%) & n (\%) & n (\%) & \\
\hline \multicolumn{5}{|c|}{ Lumbar spine } \\
\hline Normal & 7 (25.9\%) & $3(8.6 \%)$ & 15 (22.4\%) & 0.286 \\
\hline Osteopenia & $10(37 \%)$ & II (31.4\%) & $20(29.9 \%)$ & \\
\hline Osteoporosis & $10(37 \%)$ & $21(60 \%)$ & 32 (47.8\%) & \\
\hline \multicolumn{5}{|c|}{ Femoral neck } \\
\hline Normal & I5 (55.6\%) & 7 (20\%) & 17 (25.4\%) & $0.012^{*}$ \\
\hline Osteopenia & $9(33.3 \%)$ & $18(51.4 \%)$ & $26(38.8 \%)$ & \\
\hline Osteoporosis & $3(11.1 \%)$ & $10(28.6 \%)$ & $24(35.8 \%)$ & \\
\hline
\end{tabular}

Note: $* p<0.05$. 
lumbar spine in the three groups. Among the three groups, no significant difference was found in terms of the frequency of lumbar osteoporosis, whereas a significant difference was found with regards the frequency of femoral osteoporosis ( $p=0.012$ ). Binary comparisons indicated that the frequency of osteoporosis in the women with parity $<5(11.1 \%)$, was significantly lower than in the women with parity of 5-9 (28.6\%) ( $p=0.012)$, and $\geq 10$ (35.8\%) ( $p=0.009)$. However, no significant difference was found between the women with parity of 5-9 and the women with parity of $\geq 10$ in terms of the frequency of osteoporosis $(p=0.474)$.

Table 3 presents the correlation between lumbar DXA values and BMI, parity and the duration of menopause in the three groups. No significant difference was found among the three groups regarding mean BMI values, median parity, and mean duration of menopause.

Table 4 presents the correlation between femoral DXA values and BMI, parity and the duration of menopause in the three groups. In the patients with parity $<5$, the duration of menopause was significantly longer in the patients with osteoporosis $(p=0.002)$. In the patients with parity of $5-9$, the BMI values were significantly lower in the patients with osteoporosis compared to the patients with osteopenia $(p=0.035 ; p<0.05)$. In the patients with parity of $\geq 10$, no significant difference was found among the three groups in

Table 3 Comparison of BMI, median parity, and duration of menopause according to parity and the presence of osteoporosis/ osteopenia in the lumbar spine

\begin{tabular}{|c|c|c|c|c|}
\hline \multirow[t]{2}{*}{ Parity } & \multirow[t]{2}{*}{$\begin{array}{l}\text { Osteoporosis/ } \\
\text { osteopenia }\end{array}$} & \multirow{2}{*}{$\begin{array}{l}\text { BMI } \\
\text { Mean } \pm \text { SD }\end{array}$} & \multirow{2}{*}{$\begin{array}{l}\text { Parity } \\
\text { (median) } \\
\text { Mean } \pm \text { SD }\end{array}$} & \multirow{2}{*}{$\begin{array}{l}\begin{array}{l}\text { Duration of } \\
\text { menopause } \\
\text { (years) }\end{array} \\
\text { Mean } \pm \text { SD }\end{array}$} \\
\hline & & & & \\
\hline \multirow[t]{4}{*}{$<5$} & Normal & $31.8 \pm 6.75$ & $3.7 \mathrm{I} \pm \mathrm{I} .8(4)$ & $7.7 I \pm 5.25$ \\
\hline & Osteopenia & $33.82 \pm 7.27$ & $3.2 \pm 1.93(4)$ & $3.44 \pm 3.78$ \\
\hline & Osteoporosis & $34.3 \pm 9.69$ & $3.8 \pm I .55$ (4) & $10.2 \pm 8.05$ \\
\hline & $p$-value & $0.814^{\#}$ & $0.504^{\# \#}$ & $0.074^{\#}$ \\
\hline \multirow[t]{4}{*}{$5-9$} & Normal & $35.87 \pm 4.28$ & $7 \pm I(7)$ & $3.33 \pm 1.53$ \\
\hline & Osteopenia & $33.59 \pm 7.96$ & $7.91 \pm 1.14(8)$ & $5.73 \pm 4.5$ \\
\hline & Osteoporosis & $31.08 \pm 5.55$ & $7.24 \pm 1.09(7)$ & $8.24 \pm 4.53$ \\
\hline & $p$-value & $0.368^{\#}$ & $0.109^{\#}$ & $0.112^{\#}$ \\
\hline \multirow[t]{4}{*}{$\geq 10$} & Normal & $30.7 \pm 7.86$ & $1 \mathrm{I} .67 \pm 2.23(\mathrm{II})$ & $8.33 \pm 5.86$ \\
\hline & Osteopenia & $31.14 \pm 3.88$ & $11.6 \pm 1.5(\mathrm{II})$ & $9.45 \pm 5.64$ \\
\hline & Osteoporosis & $29.6 \pm 4.4 I$ & $\mathrm{II} .4 \mathrm{I} \pm \mathrm{I} .52(\mathrm{II})$ & $8.75 \pm 4.99$ \\
\hline & $p$-value & $0.559^{\#}$ & $0.599 \#$ & $0.82 I^{\#}$ \\
\hline \multirow[t]{4}{*}{ Total } & Normal & $31.63 \pm 7.19$ & $8.88 \pm 4.11(10)$ & $7.56 \pm 5.45$ \\
\hline & Osteopenia & $32.45 \pm 6.05$ & $8.56 \pm 3.76(9)$ & $7.08 \pm 5.48$ \\
\hline & Osteoporosis & $30.83 \pm 6.02$ & $8.81 \pm 3.2(10)$ & $8.8 I \pm 5.38$ \\
\hline & $p$-value & $0.442^{\#}$ & $0.902^{\#}$ & $0.259^{\#}$ \\
\hline
\end{tabular}

Notes: "One-way ANOVA test; "\#ruskal-Wallis test.

Abbreviations: BMI, body mass index; SD, standard deviation.
Table 4 Comparison of BMI, median parity, and duration of menopause according to parity and the presence of osteoporosis/ osteopenia at the femoral neck

\begin{tabular}{|c|c|c|c|c|}
\hline \multirow[t]{2}{*}{ Parity } & \multirow[t]{2}{*}{$\begin{array}{l}\text { Osteoporosis/ } \\
\text { osteopenia }\end{array}$} & \multirow{2}{*}{$\begin{array}{l}\text { BMI } \\
\text { Mean } \pm \text { SD }\end{array}$} & \multirow{2}{*}{$\begin{array}{l}\text { Parity } \\
\text { (median) } \\
\text { Mean } \pm \text { SD }\end{array}$} & \multirow{2}{*}{$\begin{array}{l}\begin{array}{l}\text { Duration of } \\
\text { menopause } \\
\text { (years) }\end{array} \\
\text { Mean } \pm \text { SD }\end{array}$} \\
\hline & & & & \\
\hline \multirow[t]{4}{*}{$<5$} & Normal & $33.87 \pm 8.31$ & $3.73 \pm 1.62(4)$ & $5.36 \pm 5.83$ \\
\hline & Osteopenia & $31.71 \pm 7.19$ & $3.33 \pm 2.18(5)$ & $6.22 \pm 4.74$ \\
\hline & Osteoporosis & $36.8 \pm 9.43$ & $3.33 \pm 0.58(3)$ & $|8.67 \pm 2.3|$ \\
\hline & $p$-value & $0.619^{\#}$ & $0.628^{\#}$ & $0.002^{\#, *}$ \\
\hline \multirow[t]{4}{*}{$5-9$} & Normal & $32.49 \pm 3.01$ & $7.57 \pm 0.98(8)$ & $4.57 \pm 5.19$ \\
\hline & Osteopenia & $34.55 \pm 6.21$ & $7.5 \pm 1.25(8)$ & $6.78 \pm 3.66$ \\
\hline & Osteoporosis & $28.11 \pm 7.02$ & $7.2 \pm 1.03(7)$ & $9.2 \pm 5.03$ \\
\hline & $p$-value & $0.045^{\#, *}$ & $0.518^{\#}$ & $0.112^{\#}$ \\
\hline \multirow[t]{4}{*}{$\geq 10$} & Normal & $29.72 \pm 7.4$ & $11.71 \pm 1.83(\mathrm{II})$ & $8.88 \pm 6.08$ \\
\hline & Osteopenia & $31.57 \pm 3.95$ & $\mathrm{II} .77 \pm \mathrm{I} .84(\mathrm{II})$ & $8.04 \pm 4.91$ \\
\hline & Osteoporosis & $29.34 \pm 4.43$ & $1 \mathrm{I} .13 \pm 1.33(\mathrm{II})$ & $9.75 \pm 5.27$ \\
\hline & $p$-value & $0.279^{\#}$ & $0.214^{\#}$ & $0.532^{\#}$ \\
\hline \multirow[t]{4}{*}{ Total } & Normal & $31.81 \pm 7.32$ & $7.9 \pm 3.99$ (8) & $6.79 \pm 6$ \\
\hline & Osteopenia & $32.57 \pm 5.46$ & $8.89 \pm 3.61$ (9) & $7.3 \pm 4.47$ \\
\hline & Osteoporosis & $29.66 \pm 5.86$ & $9.43 \pm 2.79(10)$ & $10.32 \pm 5.54$ \\
\hline & $p$-value & $0.093^{\#}$ & $0.428^{\#}$ & $0.008^{\#, *}$ \\
\hline
\end{tabular}

Notes: ${ }^{\circ}$ One-way ANOVA test; ${ }^{\prime K}$ Kruskal-Wallis test; ${ }^{*}<<0.05$. Abbreviations: BMI, body mass index; SD, standard deviation.

terms of mean duration of menopause, median parity and mean BMI values $(p>0.05)$.

\section{Discussion}

Maternal calcium turnover is increased during pregnancy and lactation. In particular, maternal-fetal calcium transfer is further increased at week 20 of gestation as a result of the peak fetal demand for calcium. Approximately $25-30 \mathrm{~g}$ of calcium is transported to the fetus throughout the pregnancy, which is equivalent to $2 \%-3 \%$ of the total calcium content of the mother. ${ }^{3}$

Previous studies have indicated that the loss in maternal BMD also continues during lactation. A previous study reported that the loss of maternal BMD at the femoral neck and the lumbar spine over a 6-month lactation period was $4 \%-7 \%$, but this loss was partial and was restored after the lactation period. ${ }^{4}$ Holmberg-Marttila et al also noted that the systematic loss in maternal BMD persisted during postpartum amenorrhea, but the recovery was accelerated by the resumption of menses. ${ }^{5}$

The association between parity and BMD remains unclear. Several studies have reported that parity has a longterm supportive effect on BMD and that the loss in BMD is lower in multiparous women compared to nulliparous women. Murphy et al reported that parity is an independent predictor for $\mathrm{BMD}$ and that $\mathrm{BMD}$ increases by $1 \%$ per 
live birth. ${ }^{6}$ Both Tuppurainen et $\mathrm{al}^{7}$ and Fox et $\mathrm{al}^{8}$ found a positive relationship between parity and BMD and reported that BMD was significantly higher in multiparous women.

However, several studies have found the opposite. Of these, Allali et al evaluated the influence of parity on mineral density and the risk of postmenopausal fracture and found that the women with parity $>6$ had significantly lower lumbar and femoral BMD values compared to the women in other groups. However, the authors found no significant correlation between parity and peripheral fractures. ${ }^{9}$ In another study, Parra-Cabrera et al reported that multiparity had a deleterious effect on BMD. ${ }^{10}$ Similarly, Demir et al, ${ }^{11}$ Hillier et al, ${ }^{12}$ and Allali et $\mathrm{al}^{9}$ suggested that multiparity is a risk factor for BMD. Nevertheless, some other studies have postulated that there is no relationship between multiparity and postmenopausal osteoporosis. Of these, Turan et $\mathrm{al}^{13}$ and Demirtaş et $\mathrm{al}^{14}$ found no significant relationship between grand-grand multiparity ( $>10$ deliveries) and postmenopausal osteoporosis.

\section{Conclusion}

No significant relationship was found between multiparity and the development of lumbar osteoporosis, whereas a positive correlation was found between multiparity and the development of femoral osteoporosis in grand-grand multiparous women. It also revealed that femoral BMD significantly decreased as the number of parity increased.

Despite being limited to retrospective analysis, the present study, to our knowledge, has the largest number of patient series in the literature about the relationship between grandgrand multiparity and osteoporosis. Nevertheless, further randomized, controlled prospective studies are needed to substantiate the relationship between grand-grand multiparity and postmenopausal osteoporosis.

\section{Disclosure}

The authors report no conflicts of interest in this work.

\section{References}

1. Salari P, Abdollahi M. The influence of pregnancy and lactation on maternal bone health: a systematic review. J Family Reprod Health. 2014;8(4):135-148.

2. Engin-Üstün Y, Çağlayan EK, Göçmen AY, Polat MF. Postmenopausal osteoporosis is associated with serum chemerin and irisin but not with apolipoprotein M levels. J Menopausal Med. 2016;22(2):76-79.

3. Pitkin RM. Calcium metabolism in pregnancy and the perinatal period: a review. Am J Obstet Gynecol. 1985;151(1):99-109.

4. Polatti F, Capuzzo E, Viazzo F, Colleoni R, Klersy C. Bone mineral changes during and after lactation. Obstet Gynecol. 1999;94(1): $52-56$.

5. Holmberg-Marttila D, Leino A, Sievänen H. Bone turnover markers during lactation, postpartum amenorrhea and resumption of menses. Osteoporos Int. 2003;14(2):103-109.

6. Murphy S, Khaw KT, May H, Compston JE. Parity and bone mineral density in middle-aged women. Osteoporos Int. 1994;4(3):62-66.

7. Tuppurainen M, Kröger H, Saarikoski S, Honkanen R, Alhava E. The effect of gynecological risk factors on lumbar and femoral bone mineral density in peri- and postmenopausal women. Maturitas. 1995;21(2): 137-145.

8. Fox KM, Magaziner J, Sherwin R, et al. Reproductive correlates of bone mass in elderly women. Study of Osteoporotic Fractures Research Group. J Bone Miner Res. 1993;8(8):901-908.

9. Allali F, Maaroufi H, Aichaoui SE, et al. Influence of parity on bone mineral density and peripheral fracture risk in Moroccan postmenopausal women. Maturitas. 2007;57(4):392-398.

10. Parra-Cabrera S, Hernandez-Avila M, Tamayo-y-Orozco J, LópezCarrillo L, Meneses-González F. Exercise and reproductive factors as predictors of bone density among osteoporotic women in Mexico City. Calcif Tissue Int. 1996;59(2):89-94.

11. Demir B, Haberal A, Geyik P, et al. Identification of the risk factors for osteoporosis among postmenopausal women. Maturitas. 2008;60: 253-256.

12. Hillier TA, Rizzo JH, Pedula KL, et al. Nulliparity and fracture risk in older women: the study of osteoporotic fractures. $J$ Bone Miner Res. 2003; 18(5):893-899.

13. Turan V. Grand-grand multiparity (more than 10 deliveries) does not convey a risk for osteoporosis. Acta Obstet Gynecol Scand. 2011;90(12): $1440-1442$.

14. Demirtaş Ö, Demirtaş G, Hurşitoğlu BS, et al. Is grand multiparity a risk factor for osteoporosis in postmenopausal women of lower socioeconomic status? Eur Med Pharmacol Sci. 2014;18(18):2709-2714.
Clinical Interventions in Aging

\section{Publish your work in this journal}

Clinical Interventions in Aging is an international, peer-reviewed journal focusing on evidence-based reports on the value or lack thereof of treatments intended to prevent or delay the onset of maladaptive correlates of aging in human beings. This journal is indexed on PubMed Central, MedLine,

\section{Dovepress}

CAS, Scopus and the Elsevier Bibliographic databases. The manuscript management system is completely online and includes a very quick and fair peer-review system, which is all easy to use. Visit http://www.dovepress. com/testimonials.php to read real quotes from published authors. 